\title{
Aeropalynological Studies of the University of Lagos Campus, Nigeria
}

\author{
Olusola ADEKANMBI, Oluwatoyin OGUNDIPE
}

University of Lagos, Department of Botany and Microbiology, Lagos, Nigeria; sholaadekanmbi2000@yahoo.com

\begin{abstract}
Aeropalynological studies were conducted in four selected sites at the University of Lagos campus, in the months of February, March, April and May of 2007. One pollen-collecting bucket containing $50 \mathrm{ml}$ glycerol, $10 \mathrm{ml}$ formaldehyde and $5 \mathrm{ml}$ phenol, per site, was placed at each sampling site, namely the Botanical Garden, Lagoon Front, Engineering Department and Computer Center. The mixtures which attracted aerospore from the atmosphere were acetolysed, observed under the microscope and photomicrographs of palynomorphs were taken. The abundance of recovered pollen ranges from 64, in February to 132, in May. Recovered palynological assemblage from chemical engineering sampling point had the highest in February, Lagoon Front location had the highest in March, Computer Centre location had the highest in April and Lagoon Front had highest number of palynomorphs during May. A total of 393 palynomorphs were counted at all, belonging to 22 families. Poaceae were abundant representing $26.33 \%$ of the total pollen, Asteraceae represents $12.72 \%$, Mimosaceae (8.89\%), Ferns spores (8.64\%), Arecaceae (5.85\%) and Euphorbiacae (5.34\%) among others. The palynomorphs abundance and diversity hits the peak in May which corresponds to the wettest month of the sampled period.
\end{abstract}

Keywords: palynomorphs, aeropollen, hayfever, anemophilous, Lagos

\section{Introduction}

While the field of aeropalynology is mainly concerned with the composition of the aeropollens and its variation with time and place both at or near ground level and up aloft embracing the study of aerial dispersal from "take off" to deposition, it impinges both on the physiology of plant reproduction on one hand and on meteorology on the other and it can contribute significantly to climatology and medicine (hay fever) (Lewis et al., 1993; Newnham 2001; Snetselaar et al., 2001; Geodateyan, 1977).

The research has shown that most hayfever is caused by wind-transported pollen, although not all such plants cause hayfever (Boral, 2004; Bricchi, 1992; Faegri, 1996; Kevan, 2005). Prediction of aeroallergen is critical as well as the weather conditions under which anthesis and high pollen levels occur. Allergy symptoms and associated primary effects have been averted by beginning medication prior to exposure (Lewis et al., 1993; Marquez et al., 2002). In all, about 15 species that are known to be considerably allergenic, are seen each year on the slides from the pollen traps in the UK. There are about another five that are regularly seen but considered to be less of a problem. The air is also full of fungal spores such as Alternaria, Aspergillus and Cladosporium, at most times of the year but especially during the late summer and autumn (Kevan, 2005). Most species of pollen have some level of allergenicity but some are particularly notorious for inducing symptoms of hay fever. Cultivated plants with showy flowers are entomophilous and do not cause pollen allergies (Marquez et al., 2002).

Another practical application of aeropollens is to test models predicting biological response to future climate change. Efforts to maintain a stable and tolerable climate has made it essential to find climatically sensitive easily monitored biological indicators that respond to climate change. Routine monitoring of air borne pollen undertaken on a near-global basis could be adapted for this purpose (Anderson, 1980; Altinta et al., 2004; Dale et al., 2002; Feher and Jarai-Komlodi, 1996; McDonald and O'Driscoll, 1980; Molina, et al., 2001; Newnham, 2001; Paloma et al., 2004). Analysis of spatial and seasonal variations in pollen levels in New Zealand suggests that the timing of onset and peak abundance of certain pollen taxa should be explored as possible bio-indicator of climate change (Charles et al., 2001).

The amount of pollen in the air can differ a lot from day to day and even within days depending on the weather (Claypoole et al., 1983). It also varies enormously from one country to another, in regions of the same country and even among different cities (Kaplan, 2004). In other countries, many aeropalynological studies have been conducted for several years using different samplers (Hasnain et al., 2005; Levetin, 1991; Murray et al., 2002; Subiza et al., 1992; Tejera and Beri, 2005). Aeropalynological studies however are scarce in Nigeria (Agwu, 1992; 2004) and little or not known aeropollen data is available for the Lagos metropolis.

\section{Materials and methods}

University of Lagos Campus (Longitude 3 23'56" E and Latitude $6^{\circ} 30^{\prime} 55^{\prime \prime} \mathrm{N}$ ) lies in the heart of Lagos, the commercial center and most populous city in Nigeria. The city is characterized by tropical climate with two distinct seasons, the dry season and the wet season with the length 
of the rainy season decreasing from south to north. In the south the rainy season lasts from March to November, whereas in the far north it lasts only from mid-May to September. A marked interruption in the rains occurs during August in the south, resulting in a short dry season often referred to as the "August break." Precipitation is heavier in the south, especially in the southeast, which receives more than 120 inches $(3,000 \mathrm{~mm})$ of rain a year, compared with about 70 inches $(1,800 \mathrm{~mm})$ in the southwest. Rainfall decreases progressively away from the coast. The sampled site falls within the low-lying coastal zone with mangroves lining the brackish lagoons and creeks, while swamp forest grows where the water is fresh and surrounded in places by tropical forest and agricultural lands. Temperatures are high throughout the year, averaging from $23^{\circ} \mathrm{C}$ to $35^{\circ} \mathrm{C}$.

Pollen bucket of $25 \mathrm{~cm}$ height and $17 \mathrm{~cm}$ width made of aluminum and covered with a $5 \mathrm{~cm}$ aperture lid lined with a metal wire mesh was used to trap palynomorphs from four different locations within the University Campus including Botanical Garden, Lagoon Front, Engineering Department and Computer Center. The ground was dug considering the width and height of the pollen- collecting jar leaving $5 \mathrm{~cm}$ of the static pollen collector above the ground level following Tauber, 1974 and adapted after Agwu, 1992. About $50 \mathrm{ml}$ of glycerol was poured into the sampling jar after which $10 \mathrm{mls}$ of formaldehyde was added, followed by $5 \mathrm{mls}$ of phenol which were then put in the dug ground at all the four locations over a period of one month. The pollen trap was changed on the first day of each month. The buckets were taken to the Palynology Laboratory, University of Lagos, Nigeria where the samples were centrifuged and washed with distilled water three times. Glacial acetic acid was added to the residue and allowed to stand for five minutes following which the residues were processed by acetolysis technique (Ertman, 1969; Faegri and Iversen, 1989) and slides were made. The sampling process was repeated for three consecutive months: March, April and May of the year 2007.

The recovered palynomorphs were identified using current and past work of the author, available published work (Sowunmi, 1973; 1995) and in house albums of oil companies. Photomicrographs of pollen grains and spores were taken using an Olympus microscope mounted with a Moticam 2000 digital camera. Meteorological data were obtained from the Nigerian Meteorological Agency. The percentage abundance of each species was calculated and monthly pollen concentrations were compared with meteorological data (Mullins and Emberlin, 1997; Anderson, 1980; Altinta et al., 2004).

\section{Results}

Through the four consecutive months, a total of 65 palynomorphs were recovered from the Botanical Garden, 163 palynomorphs from sample location at Lagoon Front, 97 from Computer Centre and 68 from Chemical
Engineering. Fig. 1 shows the abundance distribution of recovered palynomorphs for the four different locations

Tab. 1. Monthly pattern of airborne palynomorphs

\begin{tabular}{|c|c|c|c|c|c|c|c|}
\hline \multirow[t]{2}{*}{ Pollen taxa } & \multirow[t]{2}{*}{$\begin{array}{c}\text { Genus and } \\
\text { species }\end{array}$} & \multicolumn{6}{|c|}{$\begin{array}{l}\text { Mean pollen counts } \\
\text { at different periods }\end{array}$} \\
\hline & & 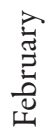 & 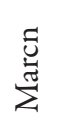 & 莒 & 严 & 苞 & $a^{\circ}$ \\
\hline Adiantaceae & $\begin{array}{l}\text { Acrostichum } \\
\text { aureum }\end{array}$ & 4 & 2 & 5 & 7 & 18 & 4.58 \\
\hline Apocynaceae & $\begin{array}{l}\text { Apocynaceae } \\
\text { pollen }\end{array}$ & & 1 & 2 & 2 & 5 & 1.27 \\
\hline $\begin{array}{l}\text { Aracaceae } \\
\text { (Palmae) }\end{array}$ & Elaeis guinensis & 5 & 3 & 4 & 1 & 13 & 3.31 \\
\hline $\begin{array}{l}\text { Aracaceae } \\
\text { (Palmae) }\end{array}$ & & 2 & 2 & 5 & 1 & 10 & 2.54 \\
\hline Asteraceae & $\begin{array}{c}\text { Tridax } \\
\text { procumbens }\end{array}$ & 7 & 9 & 11 & 13 & 40 & 10.18 \\
\hline Asteraceae & & 2 & & 7 & 1 & 10 & 2.54 \\
\hline Burseraceae & Canarium sp. & & 2 & 1 & 2 & 5 & 1.27 \\
\hline Combretaceae & & 1 & 3 & 2 & 3 & 9 & 2.29 \\
\hline Convolvulaceae & & 1 & & 1 & 1 & 3 & 0.76 \\
\hline Caesalpiniaceae & $\begin{array}{l}\text { cf. Berlinia } \\
\text { grandifolia }\end{array}$ & 2 & 1 & 2 & 2 & 7 & 1.78 \\
\hline Caesalpiniaceae & $\begin{array}{l}\text { Caesalpiniaceae } \\
\text { pollen }\end{array}$ & 1 & & 2 & 2 & 5 & 1.27 \\
\hline $\begin{array}{l}\text { Chenopodiaceael } \\
\text { Amaranthaceae }\end{array}$ & $\begin{array}{l}\text { Chenopod/ } \\
\text { Amaranth }\end{array}$ & 2 & 1 & 1 & 2 & 6 & 1.52 \\
\hline Cyperaceae & Cyperus pollen & 2 & & 2 & 1 & 5 & 1.27 \\
\hline Euphorbiaceae & $\begin{array}{l}\text { Euphorbia } \\
\text { heterophylla }\end{array}$ & 1 & & 2 & 1 & 4 & 1.02 \\
\hline Euphorbiaceae & $\begin{array}{l}\text { Alchornea } \\
\text { cordifolia }\end{array}$ & 1 & 2 & 4 & 4 & 11 & 2.80 \\
\hline Euphorbiaceae & & & 2 & 3 & & 6 & 1.52 \\
\hline Guttiferae & Pentadesma sp. & 1 & & & 1 & 2 & 0.50 \\
\hline Malvaceae & & & 2 & 3 & 2 & 7 & 1.78 \\
\hline Meliaceae & Khaya ivorensis & 2 & 1 & 1 & 2 & 6 & 1.52 \\
\hline Mimosaceae & Albizia sp. & 2 & 1 & 2 & 3 & 8 & 2.03 \\
\hline Mimosaceae & Acacia senegal sp. & 1 & & 2 & 2 & 5 & 1.27 \\
\hline Mimosaceae & $\begin{array}{l}\text { Calpocaly } \mathrm{x} \\
\text { cauliflorus }\end{array}$ & 1 & 1 & 2 & 3 & 7 & 1.78 \\
\hline Mimosaceae & $\begin{array}{l}\text { Entanda } \\
\text { albissinica }\end{array}$ & 3 & 2 & 2 & 1 & 8 & 2.03 \\
\hline Nymphaceae & Nymphae lotus & & 2 & 1 & 2 & 7 & 1.78 \\
\hline Poaceae & Grass pollen & 13 & 27 & 28 & 39 & 106 & 26.33 \\
\hline Polypodiaceae & $\begin{array}{c}\text { Polypodiaceoispo- } \\
\text { rites sp. }\end{array}$ & & & 5 & 2 & 7 & 1.78 \\
\hline Rhizophoraceae & Rhizophora sp. & & & 1 & 2 & 3 & 0.76 \\
\hline Rhizophoraceae & $\begin{array}{l}\text { Rhizophora } \\
\text { racemosa }\end{array}$ & 2 & 2 & 3 & 6 & 13 & 3.31 \\
\hline Rutaceae & cf Citrus sp. & 1 & 3 & 2 & & 6 & 1.52 \\
\hline Sapotaceae & $\begin{array}{c}\text { Chrysophyllum } \\
\text { sp. }\end{array}$ & & & 1 & 2 & 3 & 0.76 \\
\hline
\end{tabular}


36

Tab. 1. Monthly pattern of airborne palynomorphs (Continuous)

\begin{tabular}{|c|c|c|c|c|c|c|c|}
\hline \multirow[t]{2}{*}{ Pollen taxa } & \multirow[t]{2}{*}{ Genus and species } & \multicolumn{6}{|c|}{$\begin{array}{l}\text { Mean pollen counts } \\
\text { at different periods }\end{array}$} \\
\hline & & 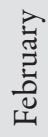 & 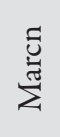 & 营 & હ & ت્ّี & de \\
\hline \multirow[t]{11}{*}{ Sapotaceae } & Sapotaceae & 2 & & 2 & 1 & 5 & 1.27 \\
\hline & Syncolporites sp. & 1 & & 3 & 2 & 6 & 1.52 \\
\hline & $\begin{array}{l}\text { Stereiosporites sp. } \\
\quad \text { (fern spore) }\end{array}$ & 1 & & 2 & 3 & 6 & 1.52 \\
\hline & $\begin{array}{l}\text { Laevigatosporites } \\
\text { (fern spore) }\end{array}$ & & & 2 & 1 & 3 & 0.76 \\
\hline & Tricolporate grain & & & & 1 & 1 & 0.25 \\
\hline & Tricolpate pollen & & & 1 & & 1 & 0.25 \\
\hline & Retitricolporites sp. & & & & 1 & 1 & 0.25 \\
\hline & $\begin{array}{c}\text { Reticulate } \\
\text { indeterminate pollen }\end{array}$ & & & & 1 & 1 & 0.25 \\
\hline & Pollen indeterminate & 1 & 1 & 2 & 2 & 6 & 1.52 \\
\hline & Fungal spore & 2 & 2 & 5 & 8 & 17 & 4.32 \\
\hline & Spore indeterminate & & 1 & 1 & 2 & 4 & 1.02 \\
\hline Total & & 64 & 72 & 125 & 132 & 393 & 100 \\
\hline
\end{tabular}

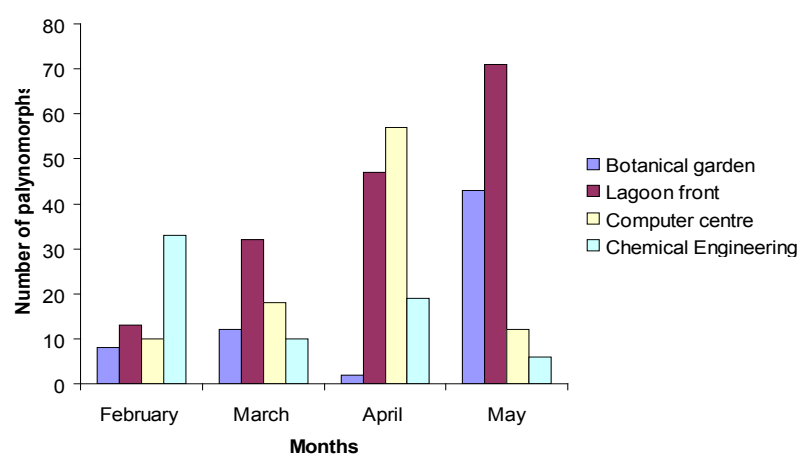

Fig. 1. Chart showing retrieved palynomorphs for the four different locations through the four consecutive months

Tab. 2. Mean abundance of palynomorphs per location from February to May 2007

\begin{tabular}{cccccc}
\hline Location/Month & February & March & April & May & Total \\
\hline Botanical Garden & 8 & 12 & 2 & 43 & 65 \\
\hline Lagoon Front & 13 & 32 & 47 & 71 & 163 \\
\hline Computer Centre & 10 & 18 & 57 & 12 & 97 \\
\hline Chemical Engineering & 33 & 10 & 19 & 6 & 68 \\
Total & 64 & 72 & 125 & 132 & \\
\hline
\end{tabular}

through the four sampled months. A total of 393 palynomorps were counted in all belonging to 22 families. Some indeterminate pollen and spore, fern spores as well as fungal spore which could not be assigned to specific families were also noted. Few recovered palynomorphs were likewise only identifiable up to family level.

Poaceae were quite abundant, representing 26.33\% of the total pollen, Asteraceae represents $12.72 \%, \mathrm{Mi}$
Tab. 3. Meteorological data showing mean values of atmospheric readings in Lagos

\begin{tabular}{cccccc}
\hline & February & March & April & May & Year \\
\hline $\begin{array}{c}\text { Temperature } \\
\text { (Max/Min) }\end{array}$ & $32 / 27$ & $30 / 27$ & $32 / 28$ & $30 / 26$ & 2006 \\
$\begin{array}{c}\text { Rainfall } \\
(\mathrm{mm})\end{array}$ & 11.5 & 73.6 & 19.1 & 336.4 & 2006 \\
$\begin{array}{c}\text { Evaporation } \\
(\mathrm{mm})\end{array}$ & 2.9 & 3.2 & 3.9 & 3.4 & 2006 \\
$\begin{array}{c}\text { Relative } \\
\text { humidity (\%) }\end{array}$ & 79 & 78 & 76 & 81 & 2006 \\
$\begin{array}{c}\text { Wind speed and } \\
\text { direction }\end{array}$ & $\mathrm{S}_{10}$ & $\mathrm{~S}_{09}$ & $\mathrm{SW}_{09}$ & $\mathrm{~W}_{16}$ & 2006 \\
$\begin{array}{c}\text { Cloud } \\
\text { (mean) }\end{array}$ & 7.0 & 7.0 & 7.0 & 7.0 & 2006 \\
\hline
\end{tabular}

mosaceae (8.89\%), Fern spores (8.64\%), Arecaceae (5.85\%) and Euphorbiaceae (5.34\%) among others (Tab. 1). Tab. 2 shows the total number of recovered palynomorphs per location for four consecutive months in the year 2007. The abundance of recovered pollen ranges from 64 in February to 132 in May. Atmospheric data gotten from the Nigerian Meteorological Agency can be found in Tab. 3. The palynomorphs abundance and diversity hits the peak in May which corresponds to the wettest month of the sampled period.

The photomicrograph of some recovered palynomorphs is displayed in Fig. 2-7. The pictures were taken at $\mathrm{x} 400$ magnification. Some of the isolated pollen grains are polyads, especially those from the Mimosaceae family, some e.g. the Malvaceae have spines on their outer wall while others have smooth exine. A significant amount of fungal spores were also recovered.

\section{Discussion and conclusions}

The pollen grains' abundance varies from one sampled site to another due to difference in geographical position, local vegetation, rhythm of plant pollination, dispersal mechanism and environmental conditions. Airborne pollen concentrations exhibit variability, as pollens from nearby vegetation exert a profound local influence as demonstrated by Frenze (2000). Moreover, the size of source area, type of pollen sampler and the distance between the sampler and the nearby vegetation all play important role in frequency of recovered aerospore. The obtained results support the view of Frenze (2000), in that high incidence of Poaceae, Asteraceae, Mimosaceae, Ferns spores, Arecaceae, and Euphorbiacae pollen were probably due to the presence of a large area of such vegetation in and around the sampling site.

Comparing the total number of palynomorphs observed with the atmospheric data collected from Nigerian meteorological agency, Cappa, Oshodi, for the year 2006 as the readings for 2007 were not yet available and the difference between last year's readings and this year's 

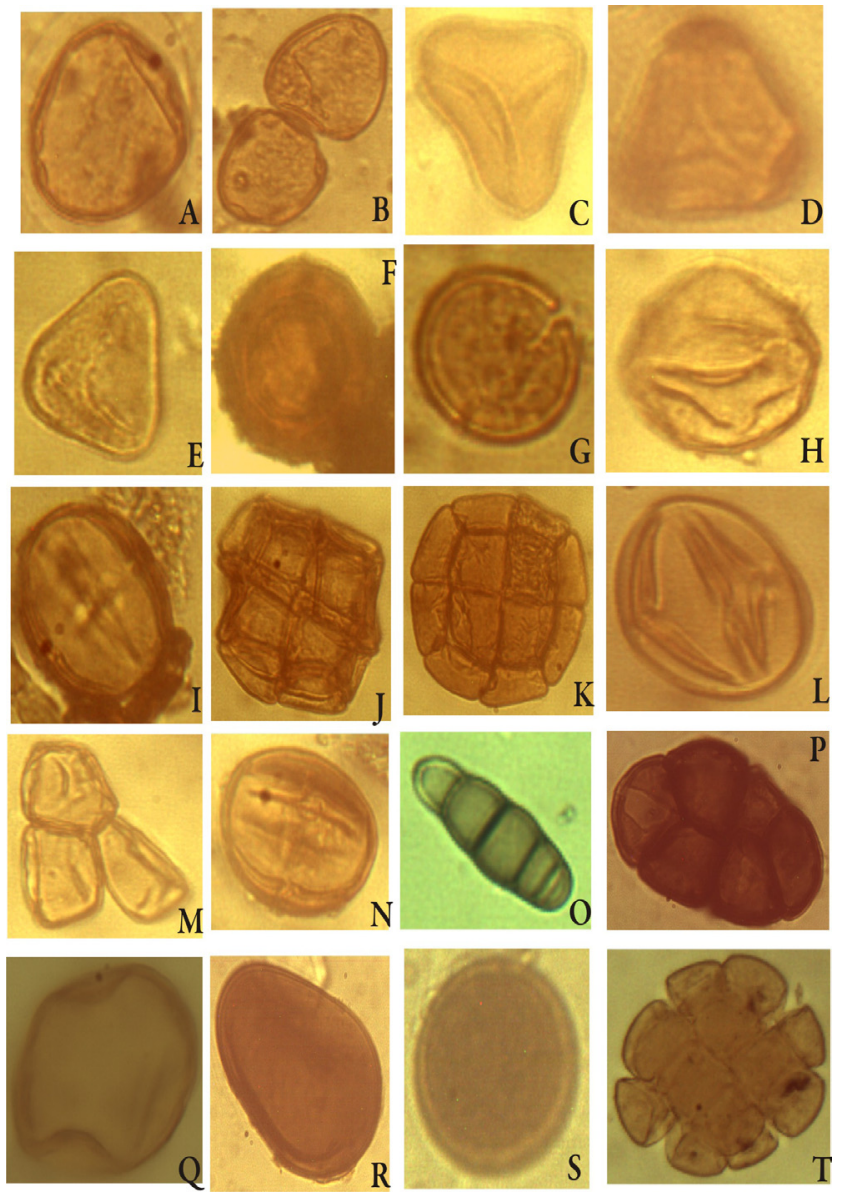

Fig. 2. A., B. Cyperus pollen (Cyperaceae); C., E. Elaeis guinensis (Aracaceae); D. Syncolporites sp.; F. Albizia sp. (Mimosaceae) sp.; G. Acacia senegal (Mimosaceae); H. Calpocalyx cauliflorus (Mimosaceae); I. three cells from polyad of $C$. cauliflorus; J. two cells from uncertain polyad; K. three cells from polyad of Albizia sp. (Mimosaceae); L. Mimosaceae pollen (Mimosaceae); M. three cells from octad of Calpocalyx sp. (Mimosaceae); N., Q. Single cells from polyad (Mimosaceae); R. cf Citrus sp. (Rutaceae); S. Laevigatosporites spore; T. Pollen indeterminate

were suggested to be plus or minus one, it was observed that the month of April and May had highest pollen abundance. It was also observed that the number of recovered palynomorphs increased over the four consecutive months for the location at Lagoon Front. This is probably due to the wind direction from the Lagoon. For February, where the maximum temperature was $32^{\circ} \mathrm{C}$ and minimum $27^{\circ} \mathrm{C}$, rainfall $11.5 \mathrm{~mm}$; these atmospheric readings favoured chemical engineering, which had the highest number of palynomorphs.

In April, where maximum temperature was $32^{\circ} \mathrm{C}$, minimum $28^{\circ} \mathrm{C}$ and rainfall $19.1 \mathrm{~mm}$, computer centre had the highest number of palynomorphs under that condition. This period coincided with the period when some trees were cut down (deforestation) from that area. It was also observed that Lagoon Front sampled location and Botanical Garden had their highest number of recovered pa-
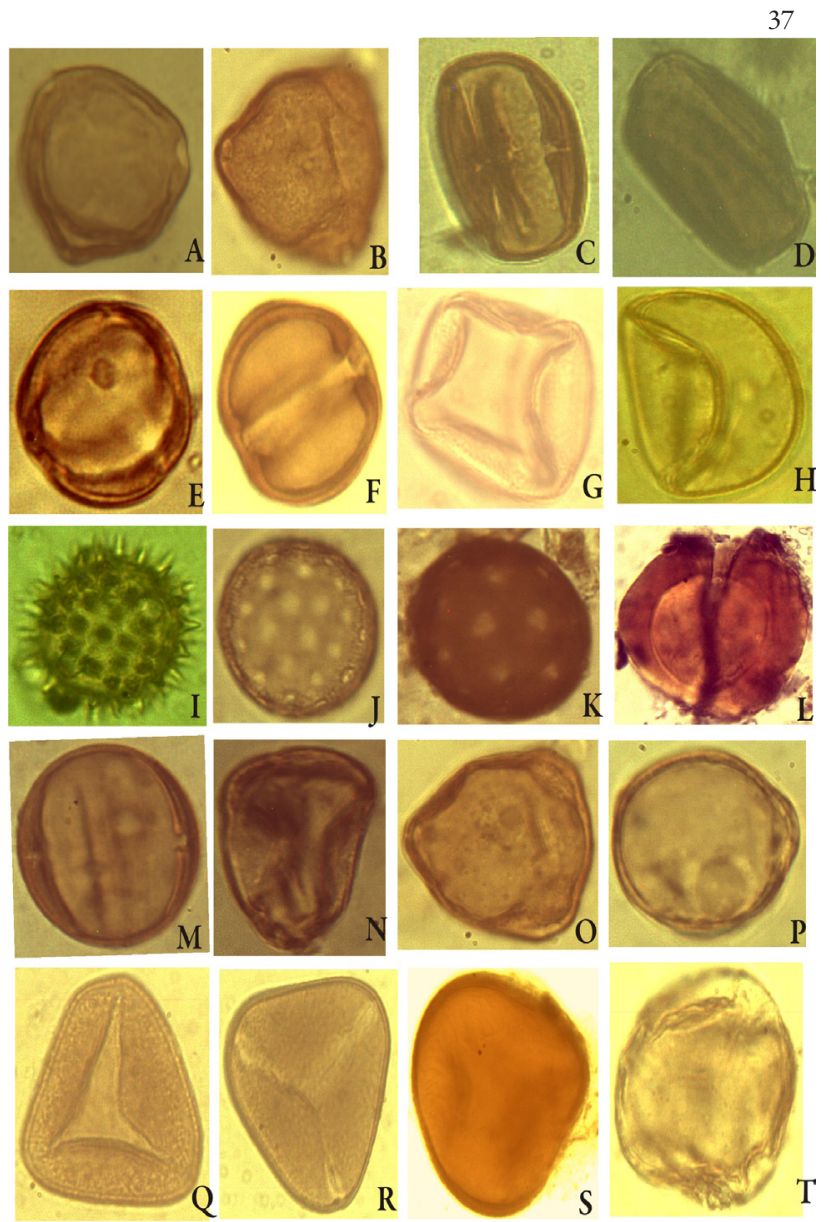

Fig. 3. A., B., E. Citrus sp. (Rutaceae); C. Sapotaceae pollen; D. Pollen indeterminate; F. Tricolpate pollen; G., H., M. Khaya ivorensis (Meliaceae); I. Tridax procumbense (Asteraceae); J, K Chenopod./Amaranth.; L. Tetracolporate pollen; N., O. Citrus sp. (Rutaceae); P. Acrostichum aureum (Adiantaceae); Q., S. Polypodiaceoisporites sp. (Polypodiaceae); R. Fern spore; T. Pollen indeterminate

lynomorphs in the month of May, which coincided with rainy season.

This aeropalynological investigation gives an idea of the airborne pollen types present in the University of Lagos atmosphere. It can be concluded from this study that atmospheric conditions especially rainfall have effects on the distribution of palynomorphs in the atmosphere. The research also helped us know that there were a larger number of pollen grains than fungal spores in the air during the sampled period. However aeropalynological sampling of 4 months is not sufficient to analyze seasonal variations of airborne pollen. It would be necessary to extend this study through the year and perhaps for at least 3 consecutive years and to other strategically placed areas, so as to achieve regional pollen calendar for the city of Lagos. This would improve our knowledge of plants' flowering season, pollen and spore dynamics and its relation to meteorological parameters 


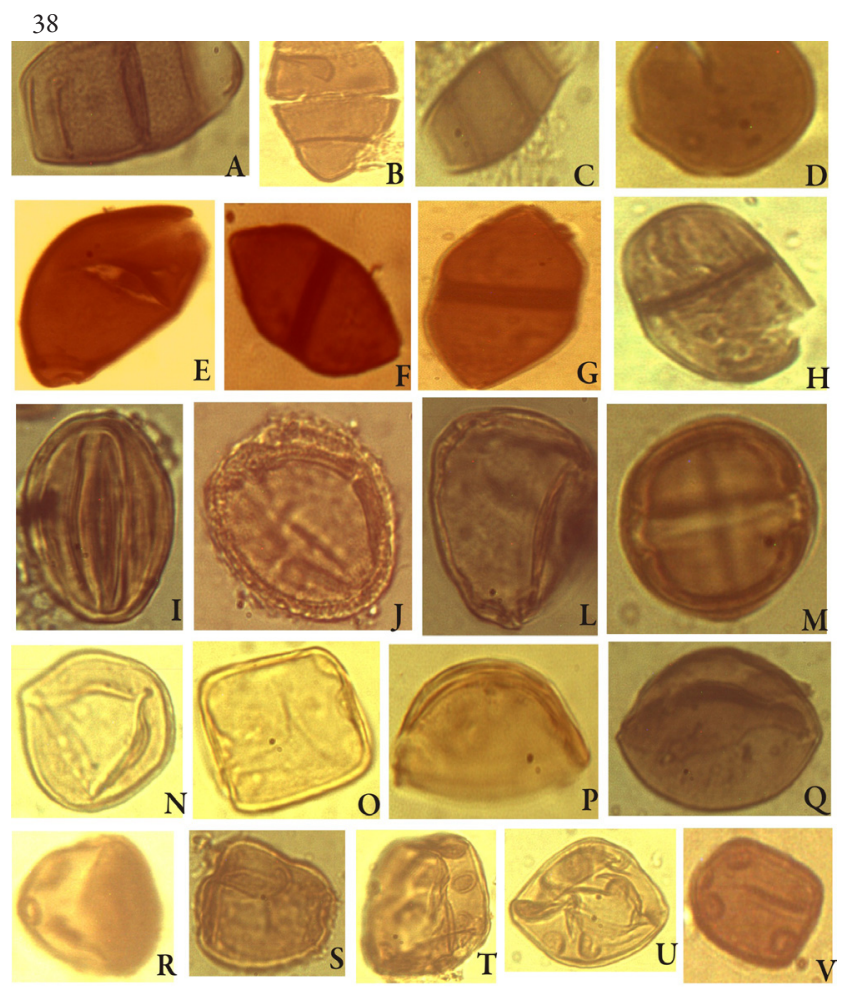

Fig. 4. A.-I. Fungal spore; J., L. Spore indeterminate; M.-O. Fern spores; P., R. Nymphae lotus (Nymphaceae); S., T. Monosulcate pollen (Palmae)
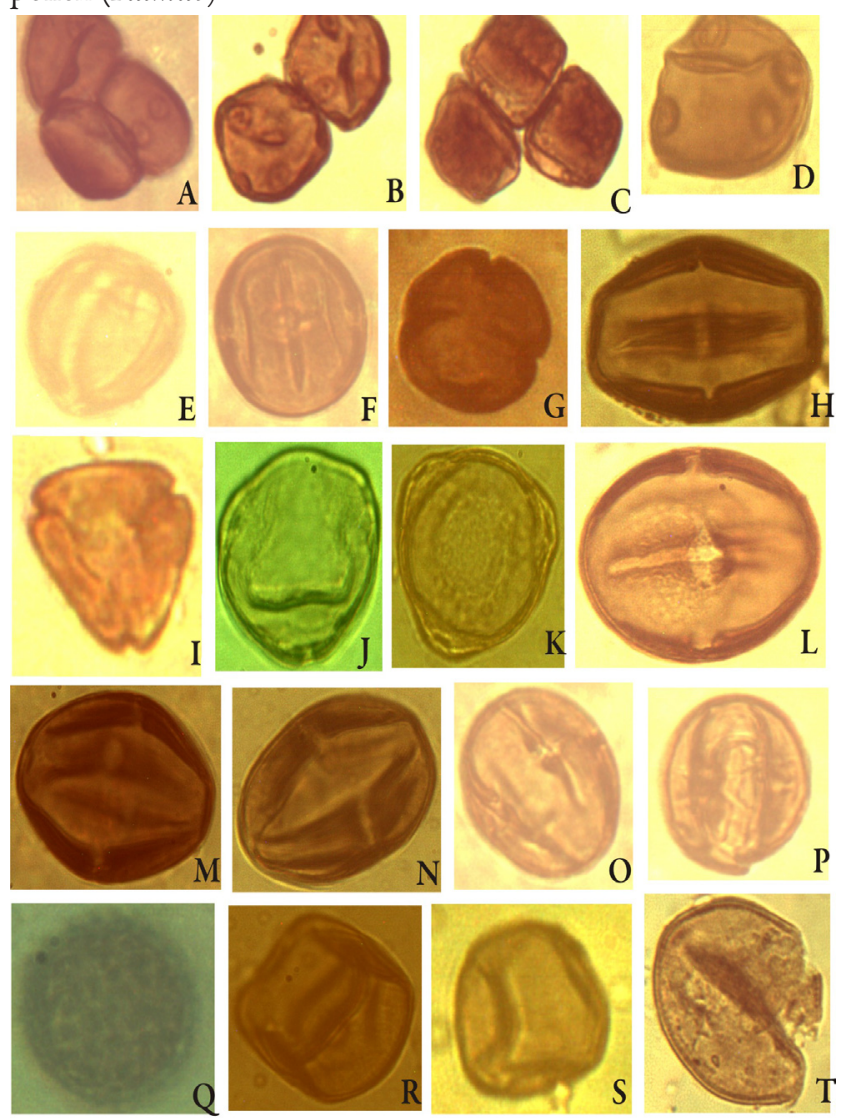

Fig. 5. A., B., E., F., G. Rhizophora sp. (Rhizophoraceae); C., D., R., S. Nymphae lotus (Nymphaceae); H. Chrysophyllum sp. (Sapotaceae); I. cf. Entanda albissinica (Mimosaceae); J., K. cf Citrus sp. (Rutaceae) L., O., P. Sapotaceae pollen; M., N. Canarium sp. (Burseraceae); Q. Asteraceae pollen; T. Stereiosporites sp. (fern spore)
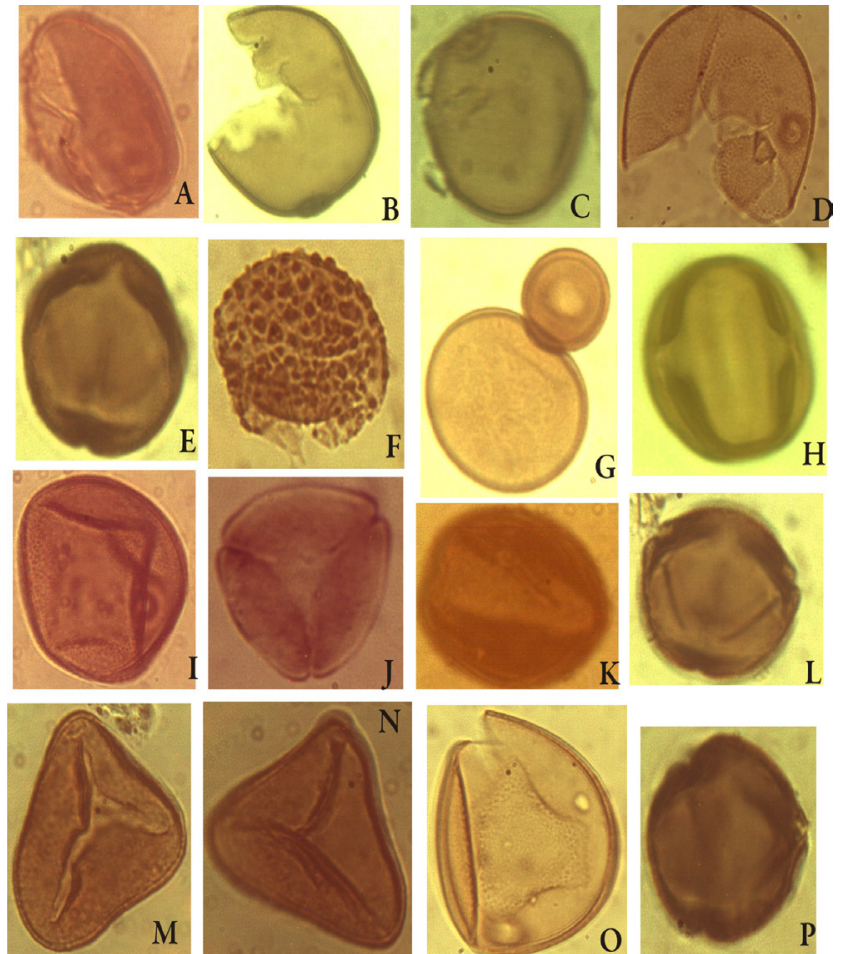

Fig. 6. A. Monosulcate pollen (Arecaceae); B.-D., I., O. Grass pollen (Poaceae); E., F., G., H., L. Sapotaceae pollen; M., N. E. guinensis (Arecaceae)
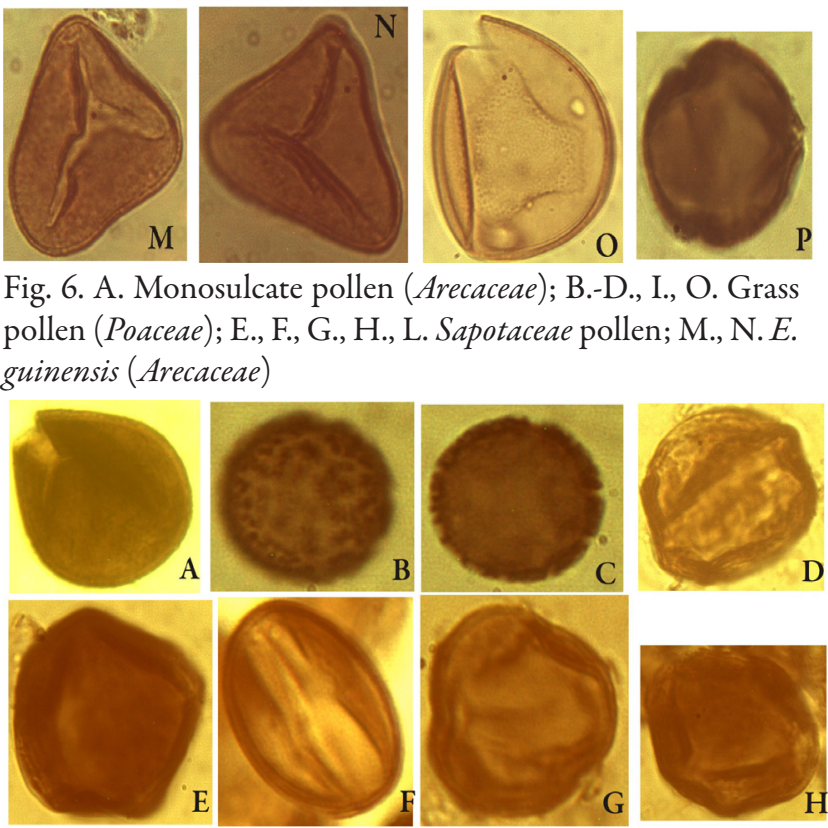

\section{P}
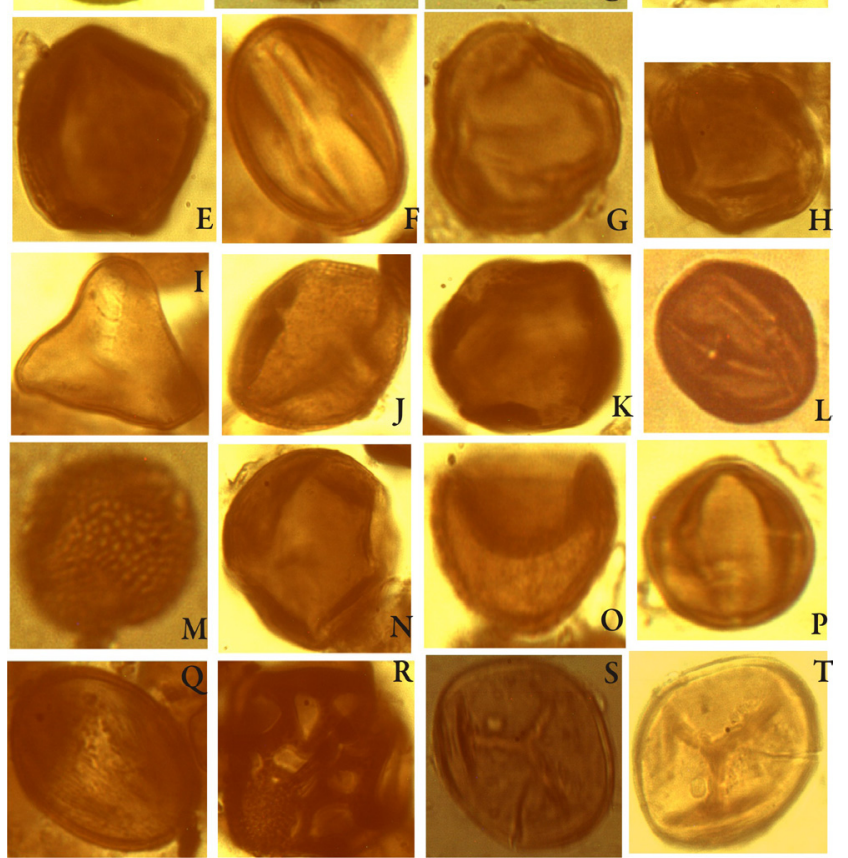

Fig. 7. A. Tricoporate grain; B. cf. Berlinia grandifolia (Caelsapiniaceae); C., K. Tricolporate pollen; D., G. Pentadesma sp. (Guttiferae); E. Elaeis guinensis (Aracaceae); F. Retitricolporites sp.; H., I. Reticulate pollen; J. Apocynaceae; L. Pollen indeterminate; M. Caesalpiniaceae pollen; N. Fern spore; O., P. Stereiosporites sp. (fern spore) 


\section{References}

Agwu, C. O. C. and E. E. Osibe (1992). Airborne palynomorphs of Nsukka during the month of February-April 1990. Nigerian Journal of Botany 5:177-185.

Agwu, C. O. C., Njokuocha, R. C. and O. Mezue (2004). The study of airborne pollen and spores circulating at "Head level" at Nsukka Bioresearch 2(2):7-14.

Anderson, S. T. (1980). Influence of climatic variation on pollen season severity in wind pollinated trees and herbs. Grana 19:47-52.

Altinta, D. U., G. B. Karakoc, M. Yilmaz, M. Pinar, S. G. Kendirli and H. Cakan (2004). The relationship between pollen counts and weather variables in East Mediterranean Coast of Turkey. Development Immunology 2:87-37.

Boral, D., S. Chatteriee and K. Bhattacharya (2004). The occurrence and allergising potential of airborne pollen in West Bengal, India. Ann. Agric. Environ. Med. 11:45-52.

Bricchi, E., M. Fornaciari, F. Giannoni, D. Greco, D. Fascini and G. Frengvelli (1992). Fluctuations of grass pollen content in the atmosphere of East Perugia and meteorological correlation (year 1989). Aerobiologia 8: 401-406.

Charles, B., P. Fredday, L. Julie, H. Frank and P. Jay (2001). The effect of temperature, relative humidity and rainfall on airborne ragweed pollen concentrations. Aerobiologia 17:61-68.

Claypoole, S. T. and U. L. Slesnick (1983). The beauty and biology of pollen. American Biology Teacher 45:366-370.

Dale, P. J., B. Clarke and E. M. G. Fontes (2002). Potential for the environmental impact of transgenic crops. Nature Biotechnology 20:567-574.

Erdtman, G. (1969). Handbook of Palynology. An introduction to the study of pollen grains and spores. Hafner Publishing Company. New York. 4

Faegri, K. and J. Iversen (1989). Textbook of Pollen Analysis. John Wiley and Sons.

Faegri, K. and P. L. Vander (1996). The principles of Pollination Ecology. Pergamon Press, New York.

Feher, Z. and M. Jarai-Komlodi (1996). Relationship between airborne ragweed pollen concentration and the macrosynoptic weather types in Budapest, Hungary. Ann. Agric. Environ. Med. 3:121-126.

Geodateyan, V. A. (1977). The Amount of Pollen as a regulator of Evolutionary Plasticity of cross pollinating plants. Doklady Biological Sciences 234:93-196.

Hasnain, S. M., K. Fatima, A. Al-Frayh and S. Al-Sedainy (2005). One-year pollen and spore calendars of Saudi Arabia AlKhobar, Abha and Hofuf. Aerobiologia 21:241-247.

Kaplan, A. (2004). Airborne pollen grains in Zonguldak, Turkey, 2001-2002. Acta Bot. Sin. 46:668-674

Kevan, P. G. (2005) Pollination by wind (anemophily), 439-464 pp. In: Practical Pollination Biology. Dafni, A., Kevan, P. G. and B. C. Husband (Eds.). Canada Environment Ltd. ncentration of airborne Basidiospores. Grana 30:123-128.

Lewis, W. H., P. Visnay and V. E. Zenger (1993). Airborne and allergenic pollen of North America. The John Hopkins University Press.

Marquez, J., J. A. Seoane-Camba and M. Suarez-ervera (2002). Allergenic and antigenic proteins released in the apertural sporoderm during the activation process in grass pollen grains. European Journal of Cell Biology 81:107-115.

McDonald, M. S. and B. J. O'Driscoll (1980). Aerobiological studies based in Galway: A comparison of pollen and spore counts over two seasons of widely different weather conditions. Clin. Exp. Allergy 10:211-215

Molina, R.T., I. S. Palacios, A. F. M. Rodriguez, J. T. Munoz and A. M. Corchero (2001). Environmental factors affecting airborne pollen concentration in anemophily species of Plantago. Ann. Bot. 87:1156-1158.

Mullins, J. and J. Emberlin (1997). Sampling pollens. J. Aeresol Sci. 28:365-370.

Murray, M. G., M. I. Sonaglion and C. B. Villamil (2002). Annual variation of airborne pollen in the city of Bahia Blance, Argentina. Grana 41:183-189.

Newnham, R. M. (2001). Aeropalynology and global warming, pp. 570. In: Goodman, D. K. and R. T. Clarke (Eds.) Proceedings of the IX International Palynological Congress, Houston, Texas, U.S.A., 1996; American Association of Stratigraphic Palynologists Foundation.

Paloma, C., G. Carmen, A. Purificacion and D. Eugenio (2004). Airborne pollen records response to climatic conditions in arid areas of the Iberian Peninsula. Environ. Exp. Bot. 52:1122.

Snetselaar, K.M., M.A. Carfioli and K. M. Ordisco (2001). Pollination can protect maize ovaries from infection by Ustilago maydis, the corn smut fungus. Canadian Journal of Botany 79:1390-1399.

Sowunmi, M. A. (1973). Pollen Grains of Nigeria Plants 1. Woody Species. Grana 13:145-186.

Sowunmi, M. A. (1995). Pollen Grains of Nigeria Plants II. Woody Species. Grana 34:120-141.

Subiza, J., J. M. Masiello, J. L. Subiza, M. Jerez, M. Hinojosa and E. Subiza (1992). Prediction of annual variations in atmospheric concentration of grass pollen. A method based on meteorological factors and grain crop estimates. Clin. Exp. Allergy 22:540-546.

Tauber, H. (1974). A static non-overload pollen collector. New Phytologist 73(2):359-369.

Tejera, L. and A. Beri (2005). First volumetric airborne pollen sampling in Montevideo City, Uruguay. Aerobiologia 21:33-41. 